\title{
Climate of Organizational Ethics to Business Satisfaction (Study of SME in South Sulawesi)
}

\author{
Muhammad Idrus Taba1, Muhammad Ismail'², Muhammad Sobarsyah ${ }^{3}$ and Tasrim ${ }^{4}$
}

\author{
${ }^{1}$ Hasanuddin University, Makassar, Indonesia \\ ${ }^{2}$ Hasanuddin University, Makassar, Indonesia \\ ${ }^{3}$ Hasanuddin University, Makassar, Indonesia \\ ${ }^{4}$ Makassar Advanced Economic School, Makassar, Indonesia
}

\begin{abstract}
Organizational ethics plays an important role in shaping a good climate for all members of the organization. The ethical issues concerning to social problem, protection of the rights of employees, public society (social responsibility) and also consumers. The application of ethics in organization raises the employee job satisfaction (see organizational justice theory and cognitive dissonance theory). This study was analyzed with the multiple regression method by taking the object of research on 350 SME businesses in three regencies, East Luwu, Bone and Tana Toraja in South Sulawesi. This study was focused in three forms, namely egoistic ethical climate, benevolent, and principled ethical climate. The results of the study show that organizational climate is like egoistic ethics climate and benevolence ethical climate the organization does not show positive results on employee job satisfaction. However, the coefficient of egoistic climate has negative influence on job satisfaction. Whereas principled ethical climate shows a positive and significant influence on employee job satisfaction.
\end{abstract}

Keywords: ethical climate and job satisfaction

\section{Introduction}

The issue of business ethics is quite complex, including as social expectations, honest competition, protection and legal rights, and social responsibility. The impact is related to consumers, employees, business competitors and the public society (Vitell Scott J and Davis, 1990). The rapidity of business globalization has increasingly led to questions about ethics in a new and different environment (Viswesvaran et al, 1998). Business ethics research generally investigates the forms and bases of moral judgments, and standards and ethics of behavior in situations involving business decisions (Vitell Scott J and Davis, 1990). Business ethics research is mostly normative with forms of empirical research that more dominating (Randall and Gibson 1990; Robertson 1993).

Empirical research is directed towards determining ethical behavior at present. The determining factors that are most studied are personal attributes (religion, nationality, gender and age), education and work experience, personality, values and beliefs (e.g. Machiavellianism, locus of control, ambiguity and role conflict), referent groups (such as the influence of professional groups, top management and also awards and sanctions), etc. such as codes of conduct, types of ethical decisions and organizational factors (Ford and Richardson, 1994).

Investigating the determinants of ethical behavior is an important step because it can enhance our knowledge about the factors related to business ethics and ethical decision making. In addition to these antecedents, the consequences of business ethics and ethical decision making are also research field that should not be neglected, especially research on the results of business ethics organizations. We can gain more by studying the relationship between the company's ethical behavior and its performance at the corporate level (e.g. financial performance). At the individual level, consequences such as job satisfaction, stress, motivation, commitment or work performance can have a significant impact on the company. Although the fields of research above are really useful but not much research.

In addition, business ethics research is carried out more in developed countries (especially western countries) where the results of researches cannot be applied to developing countries (for example, 
Asian countries). As Asian countries begin to open their doors to foreign trade and investment, there are also many business ethics research interests in this region (e.g., Zabid \& Alsagoff 1993; Cyriac and Dharmaraj 1994; Honerycutt et al 1995; Visweswaran \& Deshpande 1996 \& 1998). Nevertheless, there has been no empirical research conducted on organizational ethics in Indonesia, a country that has a high reputation as an Asian country that is corrupt and is included in the 10 most corrupt countries based on polls conducted by Transparency International based in Berlin (Sim, 1998).

This study supports the focus of social and welfare research that carries the theme of superior research that is building human beings and institutions based on local wisdom. The general objective of the research is to map the value system that underlies business conduct, related to social expectations, honest competition, protection and legal rights, and social responsibility and to see patterns of relationships between variables. The specific objective is to investigate the relationship between ethical behavior in organizations with job satisfaction in the Small and Medium Enterprises (SMEs) sector.The research contribution that will be applied is mapping the value system that underlies business ethics in the SME sector. Urgency of research can be used as a policy model in formulating regulations and ethical codes in business that are ethically in legal, social and cultural. The output that will be produced in the first year is that there is a mapping of the value system that underlies business behavior, related to social expectations, honest competition, protection and legal rights, as well as social responsibility of SME business society to create an improvement the conditions of business.

Organizational ethical climate provides collective norms that become behavioral guidelines (Tevino, 1986). For employees who get personal satisfaction by behaving ethically, conflict or dissonance will arise if organizational norms require employees to override their ethical values in order to fulfill organizational goals. The conflict between employee ethical values and organization ethical climate will decrease the level of job satisfaction. From justice theory, employees who feel that their company is more concerned with the interests of the company at the expense of employee interests and ethical values will feel that their fundamental values and personal rights have been violated. This will also reduce the level of job satisfaction.

Organizational ethics climate is employees complying rate with regulations and standard operating procedures of the organization. To measure the organizational ethics climate, there is an ethical climate questionnaire (Cullen, 1993). There are three categories of ethical climate namely (1) egoistic, which emphasizes the interests of the company; (2) benevolent/good, which emphasizes the interests of employees; and (3) principled, which emphasizes compliance with regulations and standard operating procedures. The research was applied to managers in large nonprofit organizations, Deshpande (1996) found that organizations can influence employee job satisfaction by manipulating their ethical climate. Similar results were also found by Joseph \& Deshpande (1997) in his research on the job satisfaction of nurses in non-profit hospitals.

Harris and Rabins (2005) mention that self-interest as one of the 'responsible action barriers'. Williams (1993) said that one cannot equate self-awareness and selfishness: "there is no problem (and should not be there) about why someone who cares for others might not be enough about themselves. Self-interest is as valuable as the person who has it: it can be very valuable, and it can be worthless and despicable (Bouville, 2008).

Individualism and masculinity lead to egoistic attitudes. Idealism is observed to have a positive relationship with fraud perceived by consumers, while selfishness is found to have a negative impact on perceptions of consumer fraud (Agag and El-masry, 2016). The ethical climate of selfishness does not play an important role in entrepreneurs in terms of leadership (Wang, 2015). The concept of justice theory states that employees who feel that their company is more concerned with the interests of the company (egoistic) at the expense of the interests of employees and ethical values will feel that the fundamental values as well as their individual rights have been violated and also will reduce the level of job satisfaction. This matter happens in the application of egoistic ethics to companies because egoistic ethics determines the maximization of utility from agents (Sidgwick, 
1981). However, when an entrepreneur confirms the concept of corporate sustainability, the egoistic concept is the answer (Bouville, 2008). The form of egoism is a special concern for selfinterest (Harris and Rabins, 2005). The argument of selfishness in business as a certain 'business ethic' is unacceptable, at least for practical and theoretical reasons (Debeljak and Krkac, 2008). Egoism considered in ethical theory, stating that spontaneous reaction selfishness is unethical (Martin and Schinzinger, 2005). Type of climate of personal interest seems to have a negative effect on job satisfaction (Meral Elci and Lutfihak, 2009).

\section{Research Methodology}

Based on previous studies, we propose a null hypothesis (H0) to examine the influence of the ethical climate of organizational egoistic on employee job satisfaction:

Hypothesis 1: climate of egoistic ethics organizations has no significant effect on job satisfaction. Employees who believe that their organization has a caring climate are more satisfied with their supervisor (Deshpande, 1996a). Joseph and Deshpande (1997), a caring climate significantly influences overall employee satisfaction and job satisfaction with salaries and supervisors. Benevolent ethical climate and principled contributed to forming a sense of team identification (Meral Elci and Lutfihak, 2009). Furthermore, (Meral Elci and Lutfihak, 2009) benevolent ethical climate related to organizational norms can encourage employees to care for friends, teammates, stakeholders, or the environment. Based on the suitability theory of individuals (Pervin 1968), Sims and Kroeck (1994) tested several hypotheses, one of them formulated that employees who achieve harmony between their ethical work climate and their expressions of preference tend to get positive job satisfaction. Unfortunately, they did not find significant results. Company leaders can foster employee satisfaction at various levels of employees through the perception of ethical climate except salary satisfaction (Deshpande, 1996b). Principled climate perception has a positive effect on job satisfaction (Martin and Cullen, 2006). Based on the previous studies, we propose a null hypothesis $(\mathrm{H} 0)$ to examine the influence of the ethical climate of organizational egoistic on employee job satisfaction:

Hypothesis 2: benevolent ethical climate organizations have no significant effect on job satisfaction. Egoistic ethical climate causes a negative influence on all members identities to the team, while the ethical climate is benevolent and principled to contribute to forming a sense of team identification (Meral Elci and Lutfihak, 2009). Furthermore (Meral Elci and Lutfihak, 2009) states that at the level of individual analysis, decisions based on individual rules and principles can vary for each person. At the local level, individuals make decisions that are in line with company standard rules and procedures. Ethical decisions are strongly influenced by a code of ethics from outside the organization (Upchurch, 1998). Koh and Boo (2001), the principle type of ethical climate has a significant influence on job satisfaction. A regulation on principled climate is not significantly related to aspects of job satisfaction (Deshpande, 1996a). Joseph and Deshpande (1997) report that company rules and procedure climate are the only among the three organizational climates has positive impact on satisfaction. Employee satisfaction at various levels of employees through perceptions of ethical climate except salary satisfaction (Deshpande, 1996b). Principled climate perception has a positive effect on job (Martin and Cullen, 2006). Work ethics has a meaningful relationship with job satisfaction (Yousef, 2016). Based on the previous studies, we proposed a null hypothesis to examine the influence of the ethical climate of organizational egoistic on employee job satisfaction:

Hypothesis 3: organizations principled ethical climate has no significant effect on job satisfaction. In this study some additional statements were added so that each category was rated with 5-point scale statement, ranging from 1 (strongly disagree) to 5 (strongly agree). 


\section{Result and Discussion}

The results of the ethics organization consisting of egoistic ethics, ethics benevolent and principled ethical and employee satisfaction for three districts in South Sulawesi (East Luwu, Tana Toraja, and Bone Regencies) described as follows.

Table 1 Descriptive of research variables

\begin{tabular}{lcccc}
\hline & $\begin{array}{c}\text { Job Satisfaction } \\
(\mathrm{Y})\end{array}$ & Egoistic (X1) & Benevolent (X2) & Principled (X3) \\
\hline Average & 69.35 & 11.45 & 11.79 & 12.39 \\
\hline
\end{tabular}

Source: Research Results (processed), 2018

Description of the study variables give an overview of the respondent's perceptions of a variable based on answers to each item statement. The choice of respondent's answers to the distributed questionnaires ranged from one (strongly disagree) to five (strongly agree). Interval of assessment was used to perform a category from the average of the variables by the normal distribution for each interval. Result of this research showed that the organizational egoistic ethical amounted to 11.45 with the agreed category, organization benevolent ethical was 11.79 with the agreed category, principled ethics amounted to 12.39 with the strongly agree category, and the working decision was 69.35 with the agree category (satisfied).

The movement of the research data for each district in research location carried out to test the average value comparison to draw the trend of data movement with job satisfaction as main target. Results can be seen in table 2 below.

Table 2 Comparison of mean values by regency

\begin{tabular}{lcccc}
\hline \multirow{2}{*}{ REGENCY } & \multicolumn{4}{c}{ Research variable } \\
\cline { 2 - 5 } & Egoistic (X1) & Benevolent (X2) & Principled (X3) & Job Satisfaction(Y) \\
\hline East Luwu & 11.75 & 10.99 & 11.56 & 67.28 \\
Tanatoraja & 11.40 & 11.71 & 12.54 & 67.63 \\
Bone & 11.19 & 12.68 & 13.08 & 73.14 \\
\hline
\end{tabular}

Source: Research Results (processed), 2018

Based on the comparison of mean values for the districts in the study sample, it is known that the mean value of egoistic ethics of smaller organizations provides a better level of work efficiency (does not show a relationship of influence). Whereas for full policy ethics and principled ethics, it shows the opposite of egoistic ethical. As seen in table 2 above that value the smallest average egoistic ethics and the full ethical values of policies and principled ethics in the largest organization produce the highest value of job satisfaction with the mean value (does not show a relationship of influence).

The influence of ethical climate (egoistic, benevolent and principled) and working decision as seen in table 3 below.

Table 3 The influence of organizational ethics climate on job satisfaction

\begin{tabular}{|c|c|c|c|c|c|}
\hline \multirow[t]{2}{*}{ Model } & \multicolumn{2}{|c|}{ Unstandardized Coefficients } & Standardized Coefficients & \multirow[t]{2}{*}{$\mathrm{t}$} & \multirow[t]{2}{*}{ Sig. } \\
\hline & $\mathrm{B}$ & Std. Error & Beta & & \\
\hline (Constant) & 55,566 & 3,760 & & 14,778 & .000 \\
\hline EGOISTICS (X1) & -.178 & .241 & -.05 & -741 & .460 \\
\hline${ }^{1}$ BENEVOLENT (X2) & .369 & .247 & .11 & 1,494 & .137 \\
\hline PRINCIPLED (X3) & .926 & .217 & .28 & 4,258 & .000 \\
\hline
\end{tabular}

a. Dependent Variable: Job Satisfaction (Y)

Source: Research Results (processed), 2018 
The results showed that egoistic has effect coefficient of -0.178 with a significance value of $0.460>$ 0.05 , benevolent variable influence coefficient of 0.369 with a significance value of 0.1376 , and principled variable have influence coefficient of 0.926 with a significance value equal to 0,000 . So that the egoistic and benevolent variables have no significant effect on job satisfaction (H0 is accepted). Egoistic coefficient has a negative sign and benevolent is positive. Principled ethical have a significant effect on job satisfaction ( $\mathrm{H} 0$ is rejected).

Test results statistically show that the climate of egoistic ethical of the organization does not affect employee job satisfaction. However, making decision in organization egoistic ethical can cause rejection of the employees. This thing is marked by a negative sign on the coefficient of influence of egoistic ethical variables. Organization egoistic ethical climate at least a part that will be of particular concern for business owners in developing the business. The existence can decrease employee satisfaction (Thomas et al., 2002) unethical (egoistic) cues will create dissatisfaction. The owner of the company who emphasizes self-interest cannot be accepted by company employees, (Debeljak and Krkac, 2008) study of egoistic literature is unacceptable. However, when the owner of the company thinks about the sustainability of the company then clearly selfish becomes the real answer (Debeljak and Krkac, 2008). In addition, (Bouville, 2008) said that when talking about the company sustainability concept, then the concept of his egoistic is the answer. Decisions and actions in the company are expected to contribute to the interests of organizational progress in terms of the interests of the owner will always be in the company, (Harris and Rabins, 2005) call it self-interest.

Benevolent ethical climate of organizations is not showed the significance on job satisfaction. Organizations benevolence climate are focusing on the good relations between the organization members, organization concern, the welfare and togetherness of all teams within an organization. This indicator is the result of the development of ((Cullen, 1993). The results which show insignificance do not mean benevolence ethical climate in organization can be ignored because benevolence ethical climate coefficients which is positive. In addition, this climate will provide stimulus through awareness of employees in behaving in an organization, as stated by ((Yagil, 2015) that good emotions start from awareness of needs. So, benevolence has an effect on the awareness of an employee's needs and create the satisfaction. The concept of ethical climate as togetherness perception about organization behavior, (Victor and Cullen, 1987) made the ethical climate of mutual understanding. The concept of the justice theory provides a real affirmation of the importance of mutual understanding in organization management. Application of the company's organizational ethical climate raises new challenges in terms of ethics and alignment in an understanding of ethics. Managerial practice in the application of the company ethical climate determine ethical relationship, (Parboteeah et al., 2010) found a strong link about managerial practices and ethics of the organization. The employee understanding about company sustainability became one of the factors that lead to benevolence climate relationship with job satisfaction, as described by ((Giovanni et al., 2015) that corporate sustainability strengthens the relationship of capacity building and work motivation in ethical climate, especially benevolence and principle climate.

Organization principled ethical climate statistically shows a significant influence on job satisfaction. Compliance with organizational rules and procedures is an inseparable part of the principled ethical climate. Company leaders make principled ethical (obedience to rules) as a part of decision making. Then, (Martin and Cullen, 2006) states that when leaders face dilemmas such as ethics or norms of the organization, the decision on adherence to the rule, (Meral Elci and Lutfihak, 2009), principled climate as I claim legal and professional codes. To observance of the organization climate requires all of the employee or the company to follow the rule. Corporate citizens who do not follow company rules and procedures are not viewed well in the organization. Organizational procedures that are institutionalized are considered right or wrong in the organization (Parboteeah and Kapp, 2008). Company leaders can foster employee satisfaction at various levels of employees 
through the perception of ethical climate except salary satisfaction (Deshpande, 1996b). Principled climate perception is considered to influence satisfaction (Martin and Cullen, 2006), (Yousef, 2016), (Vigoda-gadot, 2006) dan (Vigoda-gadot, 2006). The application of ethical climate in company with employee expectations can become compliant with good company. Principled ethical climate have a partial mediating effect on the relationship between benevolent leadership and moral leadership and team identification, but the egoistic ethical climate does not play an important role (Wang, 2015).

\section{Conclusion}

Employees who get personal satisfaction with ethical behavior, conflict or dissonance will arise if organizational norms require employees to override their ethical values in order to fulfill organizational goals. The conflict between the ethical values of employees and the ethical climate of the organization will reduce the level of job satisfaction. The results of the study show that egoistic and benevolence ethical climate the organization does not show positive results on employee job satisfaction. However, the coefficient of egoistic climate is negative influence for job satisfaction. Whereas principled ethical climate shows a positive and significant influence on employee job satisfaction. The influence of principled ethical climate will be a special concern for the owner of the company in generating job satisfaction for its employees by not ignoring the climate of egoistic and benevolence ethical. Improvement of principled ethical climate values can be carried out by upholding company rules or norms that become the reference for every company citizen in carrying out activities. Binding the rules as a whole gives a good and wrong picture according to the ethics that apply in an organization (company).

The results of this study contribute to the concept of justice theory which states that employees who feel that companies are more concerned with the interests of the company at the expense of employee interests and ethical values will feel that their fundamental values and personal rights have been violated. In this case, the application of the egoistic ethical climate from the justice theory view must be resolved by the company. Justice in organizational ethical application by paying attention to the interests of the organization not in personal matters. An egoistic climate that emphasizes the importance of the sustainability of the company provides good information in justice and ethical climate. Ethical climate as a work subsystem consisting of work procedures provides a reference for all members of the organization in acting. Alignment in the application of the organization ethical climate demands harmony in the company. The harmony in the implementation of the organizational climate with employee perceptions will provide a better ethical atmosphere especially in improving job satisfaction

\section{References}

Agag, G. M. and El-masry, A. A. (2016) 'Cultural and religiosity drivers and satisfaction outcomes of consumer perceived deception in online shopping', internet research, 26(4), pp. 942-962. doi: 10.1108/IntR-06-2015-0168.

Bouville, M. (2008) 'On Using Ethical Theories to Teach Engineering Ethics', sci eng ethies, 14, pp. 111-120. doi: 10.1007/s11948-007-9034-5.

Cullen, J. B. B. V. and J. W. B. (1993) 'THE ETHICAL CLIMATE QUESTIONNAIRE: AN ASSESSMENT OF ITS DEVELOPMENT AND VALIDITY’, Psychological Reports, 73, pp. $667-674$.

Debeljak, J. and Krkac, K. (2008) ““' Me , myself \& I "”: practical egoism, selfishness , self-interest and business ethics', SOCIAL RESPONSIBILITY JOURNAL, 4(1), pp. 217-227. doi: $10.1108 / 17471110810856974$.

Deshpande, S. P. (1996a) 'Ethical climate and the link between success and ethical behavior : An ...', Journal of Business Ethics, 15(3), pp. 315-320. 
Deshpande, S. P. (1996b) 'The impact of ethical climate types on facets of job satisfaction : An empirical investigation', Journal of Business Ethics, 15(6), pp. 655-660.

Giovanni, M. G. et al. (2015) 'The Impact of Human Resource Management Practices and Corporate Sustainability on Organizational Ethical Climates : An Employee Perspective', J Bus Ethics, 126, pp. 325-342. doi: 10.1007/s10551-013-1946-1.

Martin, K. D. and Cullen, J. B. (2006) 'Continuities and Extensions of Ethical Climate Theory: A Meta-Analytic Review', Journal of Business Ethics, 69, pp. 175-194. doi: 10.1007/s10551006-9084-7.

Meral Elci and Lutfihak, A. (2009) 'The Impact of Perceived Organizational Ethical Climate on Work Satisfaction', pp. 297-311. doi: 10.1007/s10551-008-9709-0.

Parboteeah, K. P. et al. (2010) 'Establishing Organizational Ethical Climates : How Do Managerial Practices Work?’, Journal of Business Ethics, 97, pp. 599-611. doi: 10.1007/s10551-010-05279.

Parboteeah, K. P. and Kapp, E. A. (2008) 'Ethical Climates and Workplace Safety Behaviors : An Empirical Investigation', Journal of Business Ethics, 80, pp. 515-529. doi: 10.1007/s10551007-9452-y.

Thomas, J. L. et al. (2002) 'The impact of ethical cues on customer satisfaction with service', Journal of Retailing, 78, pp. 167-173.

Vigoda-gadot, E. (2006) 'Citizens' Perceptions of Politics and Ethics in Public Administration : A Five-Year National Study of Their Relationship to Satisfaction with Services, Trust in Governance, and Voice Orientations', Journal of Public Administration Research and Theory, 17(7), pp. 285-305. doi: 10.1093/jopart/muj018.

Vitell Scott J and Davis, D. (1990) 'The Relationship Between Ethics and Job Satisfaction: An Empirical Investigation', Journal of Business Ethics, 9(6), pp. 489-494.

Wang, M. and C. L. (2015) 'The Mediating Effect of Ethical Climate on the Relationship Between Paternalistic Leadership and Team Identification: A Team-Level Analysis in the Chinese Context', Journal of Business Ethics. Springer Netherlands, 129, pp. 639-654. doi: 10.1007/s10551-014-2189-5.

Yagil, D. (2015) 'Display rules for kindness : Outcomes of suppressing benevolent emotions', Motiv Emot, 39, pp. 156-166. doi: 10.1007/s11031-014-9418-1.

Yousef, D. A. (2016) 'The Islamic work ethic as a mediator of the relationship between locus of control, role conflict and role ambiguity A study in an Islamic country setting', Journal of Managerial Psychology, 15(4), pp. 283-302. 